\title{
Smart Growth, Better Life
}

\author{
Yun $L i^{1, a}$ \\ ${ }^{1}$ School of North China Electric Power University, Baoding 071003, China \\ a2712377880@qq.com
}

\begin{abstract}
This paper describes an index-system to measure the success of smart growth of a city. Smart Growth Theory has the three-E's goal of Economic prosperity, social Equity and Environmental sustainability and ten principles concerning sustainable development. Firstly, I refered to a large number of reference materials concerning evaluation index system and Smart Growth, learning index construction methods and important indexes from them, and then I constructed four first-level indexes including Urban land-use system, Economic system, Social system, and Ecological system to assess whether the three E goals is well achieved in a city's urban planning. Then I refined the four first-level indexes into 8 second-level indexes to evaluate whether the ten principles are fully considered in a city's development. At last, I detailed the 8 second-level indexes into 25 quantifiable third-level indexes, so we can evaluate whether the growth pattern of a city is carrying out the Smart Growth Theory successfully, based on quantitative and qualitative analysis of the city's characteristics and deficiencies, and offer some guidance and suggestions for the city's further growth planning.
\end{abstract}

Keywords: Index-system, Smart Growth, Urban planning, Sustainability

\section{Introduction of Problems in the Process of Urbanization}

With the rapid progress of urbanization process around the world, cities witness an extremely fast development, and they are expanding around like frog jumping. A large amount of good farmland is replaced, which leads to the waste of recourses, and the more and more serious pollution problems.

From the historical process of urbanization, we can know that the earliest predicament of urbanization can be dated back into the 1960s[1]. With the arrival of the new economic era, the rapid expansion of the city in some parts of the United States occupied a large number of agricultural lands, and there had been an endless trend of urban sprawl. Some large cities were extremely expanding. In the urban area, there were isolated and different types of land-use areas. Residential areas and commercial areas were distant from each other, and there boomed out a great deal of private cars, which resulted a series of traffic problems and intensifying energy consumption, destroying the urban ecology and the environment[2].

Until today, problems like continuing urban sprawl , the loss of farmland surrounding urban centers, too fast urbanization, excessive urbanization, lag urbanization, and reverse urbanization are still troubling countries that are in the procedure of implementing urbanization. Therefore, smart urban planning has become increasingly important to ensure that people have access to equitable and sustainable homes, resources and jobs.

\section{Origin of Smart Growth Theory}

Smart Growth Theory, which was first promoted by the governors of the Maryland in the United States in1997, emphasizes the importance the concerted development of the environment, society and economy, and it promotes the development style of intensity, centralization and high affectivity[3]. That's why Smart Growth Theory has the three-E’s goal of Economic prosperity, social Equity and Environmental sustainability and ten principles including:

- Mix land uses

- Take advantage of compact building design

- Create a range of housing opportunities and choices

- Create walkable neighborhoods 
- Foster distinctive, attractive communities with a strong sense of place

- Preserve open space, farmland, natural beauty, and critical environmental areas

- Strengthen and direct development towards existing communities

- Provide a variety of transportation choices

- Make development decisions predictable, fair, and cost effective

- Encourage community and stakeholder collaboration in development decisions

On the one hand, as a kind of government macro-control function corresponding to the market mechanism, Smart Growth mainly manages the urban development, the urban land-use use process and mode by means of laws, finance, finance, taxation and so on, so as to control the endless spreading of the city, improve urban land-use use efficiency, and achieve the rational growth of the city.

On the other hand, Smart Growth also pays attention to the coordinated development of the environment, society and economy, emphasizing the transformation of existing communities and full use of existing equipment, as well as the organic connection between quality of life and development, advocating a compact, centralized and efficient development model. That's to say, Smart Growth is not opposed to urban development, but to solve the problem of how to develop and how to use a more reasonable and more effective way to build the city, managing urban land-use well.

Last but not the least, how can we measure whether the present growth pattern of a city is carrying out the Smart Growth Theory successfully? And in which aspects do the city's future urban planning should pay more attention to, based on the Smart Growth Theory? That's why I construct the index-system to evaluate the success of smart growth of a city.

\section{Establishment of Index-system to Evaluate Smart Growth}

The index-system I build, which is based on Smart Growth Theory, is used to measure whether the model of a city's present urban growth is reasonable and conforms to the objectives and principles of the Smart Growth Theory[4]. Therefore, I need to find a group of representative, comprehensive, quantifiable indexes of portfolio, so that we can do a quantitative analysis of the target city. First of all, I refered to a large number of reference materials concerning evaluation index system and Smart Growth, learning index construction methods and important indexes from them. And then I build this index-system to evaluate the success of smart growth of a city, based on the Smart Growth Theory's three goals of and ten principles, which can be summarized as five aspects including the land use, living facilities, regional characteristics, ecological environmental protection and economic development.

\subsection{Principles of Selecting Indexes}

* Scientific principle The evaluation index should conform to the scientific principle, so that it will have a wide range of applications, requiring it meet connotation and basic principles of Smart Growth.

* Operability principle This requires the evaluation index I choose support easy collection of indicator data and facilitation of the quantitative processing.

* Comparability principle In the process of actual research and analysis, the availability of all the data of different cities, which are to be evaluated, is different, and we may meet difficulties in collecting or failing to collect data of different year in vertical evaluation, so we need to use some methods to replace the missing data or delete the index in the index-system I constructed to insure that the index we get are comparable.

* Guiding principle The index should not only be capable of evaluating the current situation, but also play a role in the development of evaluation objectives. The results of the evaluation can serve the city's growth planners to develop more rational policies and regulations. 


\subsection{Selecting Evaluation Index}

By referring to the relevant data and material, I got that the most representative smart growth indexes including density, continuity, concentration, compactness, concentricity, cohesiveness, mixing and proximity[5]. And I employed four first-level indexes including Urban land-use system, Economic system, Social system, and Ecological system according the three E goals of Smart Growth to assess a city's current growth pattern. Next, I refined the four first-level indexes into 8 second-level indexes including Growth intensity, Growth efficiency, Economic level, Economic structure, Infrastructure construction, Standard of living, Historical and cultural protection and City livable level, to evaluate whether the ten principles are fully considered in a city's development[6]. Finally, those comprehensive indexes are subdivided into quantifiable third-level indexes, and the definition of each index is shown in Table 3.1. And it should be emphasized that the index system should be analyzed and selected according to the specific situation of the city to be assessed, which can ensure the correctness of the assessment conclusions.

\subsection{List of Indexes}

Table 3.1 List of indexes in the index-system to evaluate Smart Growth

\begin{tabular}{|c|c|c|}
\hline $\begin{array}{l}\text { First level } \\
\text { indexes }\end{array}$ & $\begin{array}{l}\text { Second level } \\
\text { indexes }\end{array}$ & Third level indexes \\
\hline \multirow{4}{*}{$\begin{array}{l}\text { Urban } \\
\text { land-use } \\
\text { system }\end{array}$} & \multirow{2}{*}{$\begin{array}{l}\text { Growth } \\
\text { intensity }\end{array}$} & \multirow{2}{*}{ 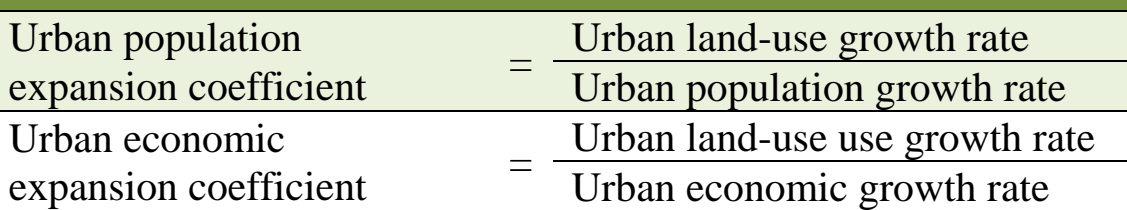 } \\
\hline & & \\
\hline & \multirow{2}{*}{$\begin{array}{l}\text { Growth } \\
\text { efficiency }\end{array}$} & $\begin{array}{l}\text { Average fiscal revenue per } \\
\text { Urban construction land }\end{array}=\frac{\text { Urban Fiscal Revenue }}{\text { Urban Construction Land }}$ \\
\hline & & Urban population density $=\frac{\text { Urban population }}{\text { Urban construction land }}$ \\
\hline \multirow{6}{*}{$\begin{array}{l}\text { Economic } \\
\text { system }\end{array}$} & \multirow{4}{*}{ Economic level } & Per capita GDP \\
\hline & & GDP growth rate \\
\hline & & Per capita fiscal revenue \\
\hline & & Per capita disposable revenue of Urban households \\
\hline & \multirow{2}{*}{$\begin{array}{l}\text { Economic } \\
\text { structure }\end{array}$} & The proportion of the tertiary industry in GDP \\
\hline & & Investment in Fixed assets \\
\hline \multirow{10}{*}{$\begin{array}{l}\text { Social } \\
\text { system }\end{array}$} & \multirow{4}{*}{$\begin{array}{l}\text { Infrastructure } \\
\text { construction }\end{array}$} & Per capita road area \\
\hline & & Amounts of public transport vehicles per million people \\
\hline & & The proportion of education funds in GDP \\
\hline & & Education level of the citizen \\
\hline & \multirow{5}{*}{$\begin{array}{l}\text { Standard of } \\
\text { living }\end{array}$} & Engel Coefficient \\
\hline & & Gini Coefficient \\
\hline & & Urban registered unemployment rate \\
\hline & & Urban registered employment rate \\
\hline & & Urbanization rate \\
\hline & $\begin{array}{l}\text { Historical and } \\
\text { cultural } \\
\text { protection }\end{array}$ & Specific analysis for different cities \\
\hline \multirow{5}{*}{$\begin{array}{l}\text { Ecological } \\
\text { system }\end{array}$} & \multirow{5}{*}{$\begin{array}{l}\text { City } \\
\text { level }\end{array}$} & Urban greening coverage rate \\
\hline & & Per capita public green area \\
\hline & & Industrial emissions compliance rate \\
\hline & & $\begin{array}{l}\text { The equivalent sound level of urban area environmental noise } \\
\text { monitoring }\end{array}$ \\
\hline & & The proportion of Urban environment investment in GDP \\
\hline
\end{tabular}




\section{Conclusions}

(1)Urban land-use system: We evaluate the rationality of Urban land-use from the two aspects including growth intensity of Urban land-use use and Urban land-use growth efficiency. As we can see, the former is depended on the city's economic development and population expansion, while the latter is reflected in the city's fiscal revenue and population density.

(2)Economic system: Economic level and economic structure are the important indexes to evaluate urban economic development. Per capita GDP, Per capita fiscal revenue and Per capita disposable revenue of urban households are significant scale leverage of economic development quality, while the proportion of the tertiary industry in GDP and investment in fixed assets measure the rationality of economic structure.

(3)Social system: Urban infrastructure construction is an important guarantee for the lives of residents, which we can evaluate from the traffic, education and other aspects. The level of life quality is an important prerequisite for the realization of social equity, which is embodied in the Engel coefficient, employment rate and revenue distribution Gini coefficient and so on.

(4)Ecological system: The proportion of environmental investment in GDP reflects the degree of urban ecological construction, while Per capita public green area, Urban greening coverage rate, the equivalent sound level of urban area environmental noise monitoring and the proportion of urban environment investment in GDP reflect the effect of urban ecological construction.

In a word, sustainable urban development is a multi-factor comprehensive decision-making, and the index-system I build will help to evaluate whether a city's current development pattern is in smart growth , providing some help and guidance to the city's future urban planning decision-makers under the direction of Smart Growth Theory.

\section{References}

[1] Measuring Sprawl: A New Index, Recent Trends, and Future Research. Laidley T. Urban Affairs Review. 2016

[2] Better Not Bigger: How to Take Control of Urban Growth and Improve Your Community. Eben F.1999

[3] Wu Tuotian. Urban shrewd growth and land use research [J]. Heilongjiang Science andTechnology Information, 2016, (07): 290.

[4] The overall situation of urban ecological evaluation index system and the wisdom of buildingresearch [D]. Harbin Institute of Technology, 2014.

[5] Cheng MJ. Nanjing city growth evaluation and optimization based on smart growth perspective. [D]. Nanjing Normal University, 2012.

[6] Cao Bin, Lin Jian-yi, Cui Sheng-hui.Study on the evaluation index system of sustainabledevelopment [J] .Chinese Journal of Environmental Science and Technology, 2010,(03). 